\title{
Two drip irrigation rates and two emitter placements on tomato production ${ }^{1,2}$
}

\author{
Adriano Navarro and James Newman
}

\begin{abstract}
The effects of two drip irrigation rates and two emitter placements on tomato production were investigated in the U. S. Virgin Islands. There was significant difference in yields between irrigation rafes but none between emitfer placements. With tomato variety N-69, marketable yields of 45 and 55 fons/ha were oblained from irrigation rates of 5.2 and $9.9 \mathrm{~mm}$ per week, respectively. The relationship of production to rainfall and potential evapotranspiration is discussed.
\end{abstract}

\section{RESUMEN}

Dos regímenes de riego por goteo para tomateras

Este estudio se llevó a cabo para determinar el efecto de dos regímenes de riego por goteo (5.2 y $9.9 \mathrm{~mm}$. por semana) con dos emisores, uno colocado sobre el terreno y el otro subterráneo, en la producción de tomates. Los resultados indican que se pueden lograr producciones significativamente más elevadas si se aplican $9.9 \mathrm{~mm}$. por semana. Por otro lado, con la aplicación de $5.2 \mathrm{~mm}$. el agua se usó más eficientemente. También se lograron producciones similares con los emisores colocados de ambas maneras.

\section{INTRODUCTION}

The climate of the U. S. Virgin Islands is characterized by constant wind movement ranging from 8 to 24 kilometers per hour, by high temperatures, and by low and often erratic rainfall (9). Average yearly rainfall is approximately $1118 \mathrm{~mm}$, but most of it is lost to the atmosphere by evapotranspiration. It is estimated that approximately 20 to $80 \mathrm{~mm}$ of the rainfall enters the underground aquifer, and about $20 \mathrm{~mm}$ flows overland into the ocean (10).

The limited water resource, aggravated by long periods of dry weather during the year (1), is a major obstacle to increasing food production in the U.S. Virgin Islands. Without irrigation it is almost impossible to produce a good crop, particularly vegetables. But since water is a limited resource and therefore expensive, its use for irrigation is justified only if used efficiently with high value crops.

${ }_{1}$ Manuseript submitted to Editorial Board 2 May 1988.

2This Project was funded by the Tropical and Subtropieal Agricultural Researeh Grant (PL 89 - 808).

${ }^{3}$ Irrigation Specialist and Technician, UVI Agricultural Experiment Station, St. Croix, USVI 00850 . 
Drip irrigation is the most efficient method known today. It has been reported that with drip irrigation, water use can be reduced by $50 \%$ or more without impairing erop yield or quality (5). Efficiency of the drip method of irrigation might be enhanced in combination with other water conservation methods such as precision monitoring and scheduling of irrigation, and by minimizing evaporation.

This study was conducted to evaluate the influence of two different rates of water application and emitter placement on tomato production in St. Croix, U.S. Virgin Islands.

\section{MATERIALS AND METHODS}

The study was conducted at the UVI Agricultural Experiment Station in St. Croix where annual average temperature is $26^{\circ} \mathrm{C}$ and annual average rainfall is approximately $1132 \mathrm{~mm}$. Annual evaporation exceeds annual rainfall by $460 \mathrm{~mm}(7,9)$.

The soil is Fredensborg clay loam. This series consists of well-drained soils formed over limestone or marl (9).

The irrigation system was installed a week before transplanting. The mainlines and submains were $12.7 \mathrm{~mm}$ polyethelene tubes. The laterals were $12.7 \mathrm{~mm}$ bi-wall tube with factory-installed emitters (Netafim Irrigation Ine.) spaced $46 \mathrm{~cm}$ apart. From the main line, water flowed through a filter, an automatic volume controller, a flow meter and then through a pressure regulator. From there, water passes through the submain lines to the laterals which supply water to the plants.

Tomato seeds (cv. N-69, from Hawaii) were sown on 2.54-cm Jiffy pellets on December 9, 1986. Approximately 22 days after sowing, the seedlings were transplanted. Spacing was $46 \mathrm{~cm}$ between plants and 91 $\mathrm{cm}$ between rows. Each row was 9 meters long. There were four rows to a treatment. After transplanting, one tensiometer was installed per treatment. The tensiometer was placed approximately $10 \mathrm{~cm}$ from the plant and at a depth of approximately $15 \mathrm{~cm}$.

The treatments were two levels of water, "high" and "low". For the high level, the tensiometer readings were maintained between 20 and 30 centibars. Irrigation was applied when tensiometer reading exceeded 30 centibars. For the low water level, tensiometer readings were maintained between 40 and 50 centibars. Irrigation was applied when tensiometer reading exceeded 50 centibars.

The other treatments were emitter placements, surface and sub-surface placements. For the subsurface placement, the bi-wall laterals were buried about 8 to $10 \mathrm{~cm}$ beneath the soil surface. Under the two levels of irrigation, the total amount of water applied was divided equally between the two emitter placements.

The experimental design was a split-plot with three replications. Irrigation levels and emitter placements were the main plots and subplots, respectively. 
A week after transplanting, the plants were fertilized with a $20-20-20$ commercial mixture at the rate of $1 / 2$ tablespoon (approximately 6 grams) per plant. The fertilizers were applied around each plant and covered with soil. When about fifty percent of the plants started to flower, the same fertilizer mixture was applied at the rate of 1 tablespoonful per plant in the same manner as the first application.

The tomatoes were harvested at the full ripe and turning stages. A total of eight pickings were made. The first picking was performed approximately 64 days after transplanting and some 86 days after sowing. The final picking was on April 6, 1987. At harvest, the weight and number of marketable and non-marketable fruits were recorded.

Weekly potential evapotranspiration rates were estimated according to the formula developed by Fleming (4):

$$
\begin{aligned}
& E_{t}=f_{1} E_{0} \\
& \text { where: } E_{t}=\text { Rate of potential evapotranspiration } \\
& f_{1}=\text { Crop coefficient } \\
& E_{0}=\text { U.S. Class A pan evaporation } \times 0.8
\end{aligned}
$$

Hoare and co-workers also presented $f_{1}$ values for various crops and $f_{1}$ for tomatoes was reported as 1 . A formula for adjusting $f_{1}$ based on the fraction of the ground covered by the plants was also reported (6). The formula is as follows:

$$
\begin{aligned}
& \mathrm{f}^{1}=\mathrm{f}_{1}[\mathrm{GC}+\mathrm{t} / 2(1-\mathrm{GC})] \\
& \text { where: } \mathrm{f}^{\mathrm{t}}=\text { Corrected } \mathrm{f}_{1} \\
& \quad \mathrm{GC}=\text { Fraction of the ground covered by the plants }
\end{aligned}
$$

$\mathrm{GC}$ values for this experiment were determined to be 12,50 and 67 percent for January, February and March, respectively.

\section{RESULTS AND DISCUSSION}

The rate and frequency of irrigation that are depicted in figure 1 were determined largely either by climatic conditions, production method or possibly by plant requirements for moisture. In January, the rate and frequency of irrigation applications were solely dictated by production techniques. High amounts of irrigation water were supplied to the newlytransplanted seedlings not as a response to climatic conditions, or to moisture demand by plants but merely, as a precaution to minimize seedling mortality and hasten plant establishment. It was a different situation in February. Because of the relatively drier weather (fig. 2) and possibly of the increased requirements for moisture of plants that were at the peak of their growth, irrigation was applied more frequently to maintain soil moisture tensions at desired levels. During the three-month eropping period, the least amount of imigation water was used in March because of the humid weather. 


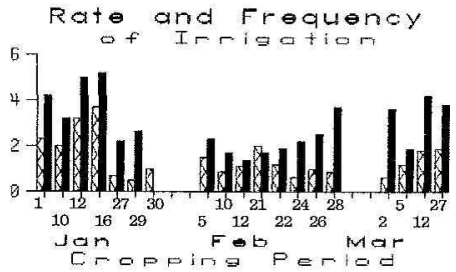

Fig. 1.-Rate and frequency of irrigation during the cropping period.

Irrigation applications during the entire cropping period averaged approximately 5.2 and $9.9 \mathrm{~mm}$ per week for the low and high level treatments, respectively.

Irrigation and potential evapotranspiration $\left(\mathrm{E}_{\mathrm{t}}\right)$ rates are presented in table 1.

Except during January, weekly $\mathrm{E}_{\mathrm{t}}$ rates were greater than irrigation rates. Moisture deficits with low irrigation were greater than the deficits with high irrigation. This probably accounts for subsequent yield differences.

Rainfall received during the cropping period has contributed substantially (table 2). With high irrigation, rainfall brought total available moisture close to that of evapotranspiration. However, with low irrigation, a net moisture deficit remained. On a weekly basis, these deficits ranged from $4.8 \mathrm{~mm}$ in February to $6.4 \mathrm{~mm}$ in March. In spite of the moisture deficits, the treatment with the lower rate of irrigation still managed to produce satisfactory yields (table 3 ). This suggests that tomatoes, or at least this variety, can tolerate such deficits while maintaining acceptable production capacity. In addition, moisture conditions in the deeper layers of the soil may need to be observed and root profiles examined. It is possible that unmeasured water was being utilized.

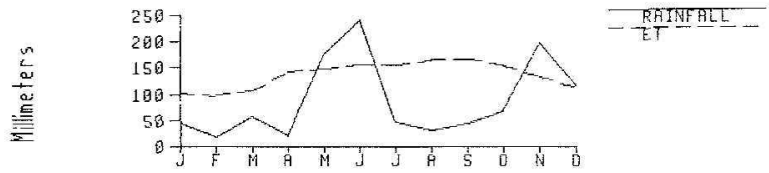

1987

FIG. 2.-Rainfall and potential evapotranspiration (Et) patterns in 1987. 
TABLE 1.-Average weekly irrigation application and potential evapotranspiration $\left(E_{t}\right)$ during each month of the cropping period, in $\mathrm{mm}$

\begin{tabular}{|c|c|c|c|c|c|c|}
\hline \multirow{3}{*}{$\begin{array}{l}\text { Irrigation }{ }^{1} \\
\text { treatment }\end{array}$} & \multicolumn{6}{|c|}{ Cropping Period } \\
\hline & \multicolumn{2}{|c|}{ January } & \multicolumn{2}{|c|}{ February } & \multicolumn{2}{|c|}{ March } \\
\hline & Rate & $\mathrm{E}_{\mathrm{t}}$ & Rate & $\mathrm{E}_{\mathrm{t}}$ & Rate & $\mathrm{E}_{\mathrm{s}}$ \\
\hline Low & 7.2 & 12.5 & 5.5 & 17.2 & 3.0 & 21.4 \\
\hline High & 12.1 & 12.5 & 10,4 & 17.2 & 7.2 & 21.4 \\
\hline
\end{tabular}

'Average weekly U.S. Class A pan evaporation values for the months of January, February and March, 1987 were 28,1, 28.6 and $32 \mathrm{~mm}$, respectively.

TABLE 2.-Combined average weelbly imigation plus precipitation $(I+P)$ during the cropping period, in $\mathrm{mm}^{i}$

\begin{tabular}{lcccccc}
\hline \multirow{2}{*}{$\begin{array}{l}\text { Irrigation } \\
\text { treatment }\end{array}$} & \multicolumn{4}{c}{ Combined Weekly Irrigation and Precipitation } \\
& $\mathrm{I}+\mathrm{P}$ & $\mathrm{E}_{\mathrm{t}}$ & $\mathrm{I}+\mathrm{P}$ & $\mathrm{E}_{\mathrm{t}}$ & $\mathrm{I}+\mathrm{P}$ & $\mathrm{E}_{\mathrm{t}}$ \\
\cline { 2 - 7 } & 17.3 & 12.5 & 12.4 & 17.2 & 15.0 & 21.4 \\
\hline Low & 22.1 & 12.5 & 17.3 & 17.2 & 19.3 & 21.4 \\
\hline High & & &
\end{tabular}

Average weekly U.S. Class A pan evaporation values for the months of January, February and March, 1987 were $28.1,28.6$ and $32 \mathrm{~mm}$, respectively.

TABLE 3.-Marketable tomato production as influenced by rate of irrigation and emitter placement, tons/ha

\begin{tabular}{lcccc}
\multirow{2}{*}{$\begin{array}{l}\text { Average weekly } \\
\text { irrigation, mat }\end{array}$} & \multicolumn{2}{c}{ Emitter placement } & \\
\cline { 2 - 4 } & Subsurface & Surface & Mean' \\
\hline Low & $(5.2)$ & 43.9 & 46.9 & $45.4^{\mathrm{z}}$ \\
High & $(9.9)$ & 54.3 & 55.0 & $54.6^{\mathrm{b}}$ \\
\hline Mean & & $49.1^{\mathrm{a}}$ & $51.0^{\mathrm{a}}$ &
\end{tabular}

Mean values bearing unlike letters differ significantly $(P>0.05)$. Values with the same letters do not differ significantly.

Table 3 presents the total marketable yields of tomatoes as influenced by irrigation rates and emitter placement. Yield from high irrigation is statistically greater than at the low irrigation.

Possibly because of more optimum plant population and better variety, crop-water use in the present study was slightly lower than that observed in previous studies at the same location. Navarro (8) reported in 1982, two field experiments where different irrigation rates were applied to maintain predetermined tensiometer values. His first experi- 
TABLE 4.-Average production of tomatoes per liter of irrigation water applied (water use efficiency)

\begin{tabular}{lcccc}
\hline & & \multicolumn{2}{c}{ Production in grams } & \\
\cline { 3 - 5 } Irrigation rate & & Subsurface & Surface & Mean \\
\hline Low rate & $(5.2)$ & 75 & 80 & $78^{\mathrm{a}}$ \\
High rate & $(9.9)$ & 49 & 49 & $49^{\mathrm{b}}$ \\
\hline Mean & & 62 & 64 & \\
\hline
\end{tabular}

'Differences between means with different letters are significant at the $1 \%$ level.

ment utilized a determinate tomato variety, Royal Chico. Optimum yield was obtained with $6.4 \mathrm{~mm}$ of water per week. However, in the second experiment using the indeterminate variety Tropic (similar to that used in the present study), and including fertilizer as another variable, he obtained highest yields from plants irrigated with $14.7 \mathrm{~mm}$ per week.

Emitter placement, however, did not have significant influence on yield. The possible advantages of subsurface placement over surface placement, one of which is reduced evapotranspiration, was not observed in this study. This may have been due to the shallow placement of the emitters which caused the wetness to extend to the ground surface. This would not have been the case if the emitters were placed at greater depth. Davis et al. (2) reported a case in which tomato yield, quality and evapotranspiration rates were not affected by surface or subsurface emitter placement when irrigation frequencies and volumes were equal. Although the volume and irrigation frequencies for both emitter placements in this study were the same, the results on the effects of placements might have been different if the subsurface emitters were placed deeper than they were. It is possible that, had the emitters been placed deeper, evaporation would have been materially lower. If so, yields from the low irrigation treatment might have been appreciably greater. The results of Davis might pertain to conditions of nonlimiting supply of irrigation water, which was not the case in the present study.

In order to determine water-use efficiency, production values were converted to grams of marketable product per liter of water applied (table 4). The low application appeared to be the more effective rate. A similar observation was made by English (3). He stated that by under-irrigating a field crop, the yields may be reduced, but capital outlays and operating costs associated with irrigation can also be reduced. The net result can be increased income to the farmer.

\section{LITERATURE CITED}

1. Bowden, M. J, 1968. Water balance on a dry island. Geography publication at Dartmouth No. 6. Clark University, Mass. 
2. Davis K. R., C. J. Phene, R. MeCormick, R. B. Hatchmacher and D. W. Meek, 1985. Trickle frequency and installation depth effects on tomatoes. Proceedings 3rd International Drip/Tickle Irrigation Congress. Am. Soc. Agr. Engineers, Michigan.

3. English, M. J., 1982. Deficit irrigation frequency on crop yields. 1982. Technical conference proceedings of the irrigation association. 375 Connecticut Avenue, Silver Springs, Maryland.

4. Fleming, P. M., 1964 B. Evaporimeter relationships at Griffith, N.S.W. Trans. Int. Egrs. Aust. CE6:1.

5. Furt, R. C., D. S. Ross and H. L. Brodie, 1980. Economic comparison of trickle and sprinkler irrigation of six fruit crops in Maryland, 1978. M. Agric. Exp. Stn., Univ. M., College Park, Maryland.

6. Hoare, E. R., K. V. Garzoli and J. Blackwell, 1974. Plant water requirements as related to trickle inrigation. Proceedings second International Drip Irrigation Congress. San Diego, California.

7. Jordan, D. G., 1975. A survey of the water resourees of St. Croix, Virgin Islands. U. S. Geological Survey, Government of the U. S. Virgin Islands.

8. Navarro, A. A., 1982. Summary of vegetable crops research 1980-1981. V.I. Agric. Stn. Technical Bull. No. 4. St. Croix, U. S. Virgin Islands.

9. Rivera, L., D. Wayne, C. Farris, E. Jensen, I. Davis, C. Palmer, L. Jackson and W. McKinzie, 1970. Soil survey of the Virgin Islands of the United States, USDA, Washington, D. C.

10. Robinson, T. M., 1972. Ground water in St. Croix, U. S. Virgin Islands. U. S. Geologieal Survey, Govermment of the Virgin Islands. 
